\title{
Measuring customer satisfaction with the controllable elements of the in- store shopping experience
}

\author{
N.S. Terblanche* \\ Department of Business Management, University of Stellenbosch, Private Bag X1, \\ Matieland 7602, Republic of South Africa \\ nst@sun.ac.za \\ C. Boshoff \\ Department of Business Management, University of Port Elizabeth, PO Box 1600, \\ Port Elizabeth 6000, Republic of South Africa \\ Received December 2001
}

\begin{abstract}
Evidence from various sources suggests that satisfaction with the individual components of an in-store shopping experience will result in customer satisfaction which will lead to customer retention and loyalty over the long term. It is argued that the in-store shopping experience (ISE) at store level consists of a variety of different dimensions that can be controlled by the retailer. This study reports on two phases of a long-term study on the controllable elements of the instore shopping experience. Closely following the guidelines for multi-item scale development suggested by Churchill (1979) and based on the results of two empirical surveys, it is concluded that there are five dimensions of importance to consumers when assessing their satisfaction with an in-store shopping experience. These dimensions are merchandise value, personal interaction, merchandise variety, internal store environment and complaint handling. The proposed instrument in its current form demonstrates high levels of reliability, discriminant validity, convergent validity and construct validity.
\end{abstract}

*To whom all correspondence should be addressed.

\section{Introduction}

The marketing literature is increasingly emphasizing the importance of customer retention against the background of increasing competition and rising costs (Grönroos, 1990). Retailers in particular have been encouraged to embrace relationship marketing (Macintosh \& Lockshin, 1997) as it is supposed to simultaneously enhance sales to current customers and reduce the probability of losing them to competitors (Berry \& Gresham, 1986).

Customer retention at the retail level is particularly complex (Bingham \& Raffield, 1990) as customers can establish relationships with salespeople, stores and with the brands themselves (Macintosh \& Lockshin, 1997; Beatty, Mayer, Coleman, Reynolds \& Lee, 1996).

Loyal customers are increasingly regarded as the backbone of any business because, generally speaking, it costs less to retain an existing customer than it costs to gain a new one (Rosenberg \& Czepiel, 1984; Reichheld \& Sasser, 1990). Also, the longer a relationship between a retailer and a customer lasts, the more profitable the relationship becomes for both parties (Sirohi, Mclaughlin \& Wittink, 1998:224). Due to the importance and prominence of customer loyalty, authors have described it as 'the emerging marketplace currency for the twenty-first century' (Singh \& Sirdeshmukh, 2000:150).
The question may be raised: what drives customer retention and loyalty? Empirical evidence such as the PIMS studies of the 1990s, academic research (Rust \& Zahorik, 1993; Sirohi et al, 1998:240) and anecdotal evidence provided by theorists (Bateson \& Hoffman, 1999:290; Heskett, Jones, Loveman, Sasser \& Schlesinger, 1994; Oliver, 1997; Zeithaml, Parasuraman \& Berry, 1990:9) all support the notion of a positive link between customer satisfaction and loyalty. The bulk of evidence from all these sources suggests that satisfaction with the individual components of an in-store shopping experience will result in customer satisfaction which will lead to customer retention and loyalty over the long term.

We argue that the in-store shopping experience (ISE) at store level consists of a variety of different dimensions that can be controlled by the retailer. Some of these individual dimensions have been identified theoretically and empirically verified (Terblanche \& Boshoff, 2001). These are Personal Interaction, Physical Cues and Variety and Assortment. Whilst the existence of these three dimensions is supported by both theory and the empirical results they do not capture the total ISE. This study reports on a follow-up to empirically evaluate the other dimensions of the ISE.

\section{The objectives of this study}

This study reports on the second phase of a long-term study on the controllable elements of the ISE. The eventual 
outcome of this stream of research is expected to be a multiitem instrument to measure customer satisfaction with the controllable components of the in-store shopping experience. Based on the disconfirmation paradigm (Oliver, 1981), the first two phases of this three-phase process is to identify the dimensions of importance to consumers when assessing their satisfaction with an ISE. Only once these dimensions have been identified and empirically confirmed, can one proceed to the development of a valid and reliable instrument to measure customer satisfaction with the ISE at retailer or shop level.

\section{The scale development process}

Churchill (1979) has suggested a well-accepted procedure for the development of valid and reliable multi-item instruments. This process consists of the following steps: domain specification, generation of questionnaire items, empirical surveying, an iterative process of scale purification based on reliability assessment and validity checks and the development of norms. This process has been advanced in recent years with the availability of statistical procedures such as confirmatory factor analysis providing additional evidence of construct validity (Tull \& Hawkins, 1993:318). The process suggested by Churchill (1979) has been followed in this study whose eventual objective is to develop a valid and reliable instrument to measure customer satisfaction with the ISE.

\section{The controllable elements of the in-store shopping experience}

Berman \& Evans (1998:19) define total retail experience as all the elements that encourage or inhibit consumers during their contact with a retailer. The total retail experience is influenced by two groups of components. The first group consists of the non-controllable components. The noncontrollable components include aspects such as the adequacy of street parking and the timing of deliveries from suppliers and taxes, all of which are either uncontrollable or a retailer can exert only limited control. The controllable components, in turn, consist of a variety of in-store elements that the retailer can control, such as the number and quality of salespeople on the shopping floor, the variety of brands on offer and the volume of stock on hand. In this study the focus is on the controllable elements of the in-store total retail experience.

\section{The second survey}

A second empirical survey was conducted as suggested by Churchill (1979). The six items with the highest factor loadings that measured Personal Interaction were retained for the second empirical survey. Three of the items used to measure Physical Cues measured product quality and it was decided to retain only one of these three items. The following item was added to measure Physical Cues: 'Products that function the way they are supposed to'. Two new items, apart from the five that were used to measure Merchandise Variety and Assortment in the first survey, were added for the second empirical survey. These two items were: 'A choice of different brand names' and 'A good selection of well-known brands'. A total of sixteen items remaining from the scale purification process of phase 1 , as well as the three new items (in total nineteen items measuring personal interaction, physical cues and merchandise variety and assortment) were combined with items to measure the three remaining (untested) dimensions of ISE, namely Internal Store Environment, Product Prices and Store Policies. The latter three dimensions were measured with 9,5 and 7 items respectively. The dimensions tested in the first survey have been reported comprehensively in an earlier article (Terblanche \& Boshoff, 2001) and only the dimensions of Internal Store Environment, Product Prices and Store Policies are reported on in the following section.

\section{Internal store environment as a dimension of ISE}

Internal store environment includes all those elements that contribute towards a pleasant shopping atmosphere. These elements are shop layout, aisles that make it easy to shop, store cleanliness, well-spaced product displays and attractive décor. The retail literature suggests that customers value the convenience that physical aspects, such as store layout, offer (Gutman \& Alden, 1985; Hummel \& Savitt, 1988; Mazursky \& Jacoby, 1985; Oliver, 1981). Dabholkar, Thorpe and Rentz (1996:7), also found empirical support for the contribution of shop layout to shopping convenience and therefore positive shopping experience. Insights and evidence from the environmental psychology literature support the notion that physical surroundings can influence the attitudes as well as the behaviours of consumers in a retail shop (Donovan \& Rossiter, 1982; Darden, Erdem \& Darden, 1983; Ridgway, Dawson \& Bloch, 1990). Tangible store attributes can also be seen as the "means" by which a consumer is able to achieve a desired "end", such as a satisfying ISE (Kerin, Jain \& Howard, 1992:381). The marketing literature supports the notion that consumers use the physical environment to form attributions about service failures and base purchase decisions on inferences they make from various elements of the physical environment (Bitner, 1990; Ward, Barnes \& Bitner, 1992; Bloom \& Reve, 1990; Zeithaml, 1988). Sirohi et al (1998:237), also found that good facility design leads to enhanced perceptions of overall merchandise quality.

Sirohi et al (1998:239) measured the store appearance perception construct with 8 items. The items measure elements such as the overall appearance of the shop, clean shopping environment, wide open aisles, departments in appropriate places and well-marked aisle directions.

The physical environment and atmosphere can assume a variety of roles in the marketing and management of a retailer (Bitner, 1992:67). Firstly, it provides a visual metaphor for a retailer's total offering. In the second instance it can assume a facilitating role by assisting consumers to carry out their intended activities. For instance, the floor plan, layout of equipment and shelving can have a major impact on the ability of consumers to undertake their shopping. In the last instance, the physical environment can also serve as a differentiator to position a retailer and distinguish it from competitors. In other words, the physical environment and atmosphere consist of a wide 
range of elements. Some of the more common elements of the physical environment include the floor space allocated to various functions, traffic flow, width of aisles, fixtures, construction and finishing characteristics such as flooring, wall textures, density of merchandise, lighting and colour.

The items used to measure internal store environment were similar to those used in previous studies. The following nine items were used in the second survey to measure internal store environment:

- a pleasant shopping atmosphere;

- reasonable check-out waiting times;

- a clean shop;

- $\quad$ store layout and aisles that make it easy to shop;

- $\quad$ attractive product and promotional displays;

- well-spaced product displays;

- a convenient shopping environment;

- attractive décor; and

- a shop layout that makes it easy to find what you need.

\section{Product prices as a dimension of ISE}

Gaski and Etzel (1986) used price as a dimension in their Index of Consumer Sentiment Toward Marketing instrument because they believed that price perception will influence consumer satisfaction with the marketing discipline in general. This inclusion acknowledges the importance of price in consumer decision-making. In the absence of other cues, consumers tend to use price as an indicator of product quality (Davidson, Sweeney \& Stampfl, 1988:143). Price is a generally controllable extrinsic cue of a product that exerts an influence on the way shoppers perceive product quality (Sirohi et al, 1998:226). Price as an extrinsic cue is, for instance, very important to supermarket shoppers as they typically do not regard the time and effort to be spent in evaluating intrinsic cues as worthwhile (Sirohi et al, 1998:227). Price is one of the extrinsic cues that have received a great deal of attention in consumer research (Dodds, Monroe \& Grewal, 1991; Mazursky \& Jacoby, 1985; Rao \& Monroe, 1989) and it has been confirmed that price levels play a significant role in shoppers' retail patronage behaviour (Sirgy, Grewal \& Mangleburg, 2000:130). Kerin et al(1991:383), for instance, suggest that because of the variety of extrinsic cues available in a supermarket (e.g. cleanliness, assortment and variety), price and quality perceptions could co-vary and that consumers 'get what they pay for'. Samli, Kelly and Hunt (1998:33-34) used price in a recent study of retail image and found congruence (i.e. no differences) between the perceptions of the head office management of a major chain store and customers. Head office management and customers rated price high and this indicates that price is an important component of the image that a customer has of a shop. Price has an important bearing on customer satisfaction primarily because customer satisfaction is the result of a customer's perception of the value received and price is an important attribute of value (Anderson, Fornell \& Lehmann, 1994; Hallowell, 1996:26; Athanasspoulos, 2000:192; Cronin, Brady \& Hult, 2000).
The following items, based on those used in previous studies, were used to measure product prices as a dimension of the in-store shopping experience in the second survey:

- reasonable prices;

- $\quad$ prices that offer value for money;

- $\quad$ products at prices that represent good value;

- $\quad$ prices that reflect the value of the products; and

- $\quad$ prices that reflect the quality of the product.

\section{Store policies as a dimension of ISE}

Store policy as a dimension of ISE captures those elements that are influenced by a shop's responsiveness to the customer's needs (Dabholkar et al, 1996:7). Typical policy elements would regulate considerations such as the return or exchange of purchases, shopping hours, payment options available and a system or process to deal with customer enquiries and/or complaints (Westbrook, 1981; Mazursky \& Jacoby, 1985; Dickson \& Maclachlin, 1990: Dickson \& Albaum, 1977). Both Westbrook (1981) and Mazursky and Jacoby (1985), emphasise the importance of the ease of returning and exchanging of products for retail customers. Service recovery is also regarded as an element of policy because it is a critical element of a shop's response to a customer's need. The way in which a retailer responds to a service failure is essential for the maintenance of customer loyalty (Berry \& Parasuraman, 1991), as well as a positive ISE because a service failure and the subsequent recovery efforts create strong memories for customers (Zeithaml \& Bitner, 1996:126). Retail employees play a major role in service recovery because of customers' demand that service recovery take place on the spot and quickly. Staff should thus be equipped with the necessary skills, authority and incentives to act in an effective way and they should also be empowered to use their skills in service recovery situations (Zeithaml \& Bitner, 1996:194). A further example of a store policy, which can exert an important influence on customer satisfaction, is guaranteed satisfaction offered by a shop. Guaranteed satisfaction influences the image a customer has of a shop and it will therefore also influence ISE (Bloemer \& de Ruyter, 1998:503).

The following items, also based on previous studies, were used to measure store policy as a dimension of the in-store shopping experience in the second survey:

- a fair policy of returns and exchanges of products;

- acceptance of all major credit cards;

- convenient payment options;

- convenient hours which the shop is open for shopping;

- a fair system for the handling of complaints;

- $\quad$ an effective means of dealing with customer enquiries; and

- $\quad$ staff that efficiently deal with customer complaints.

Figure 1 is a schematic presentation of the dimensions of ISE that were subjected to empirical assessment during the second survey. 


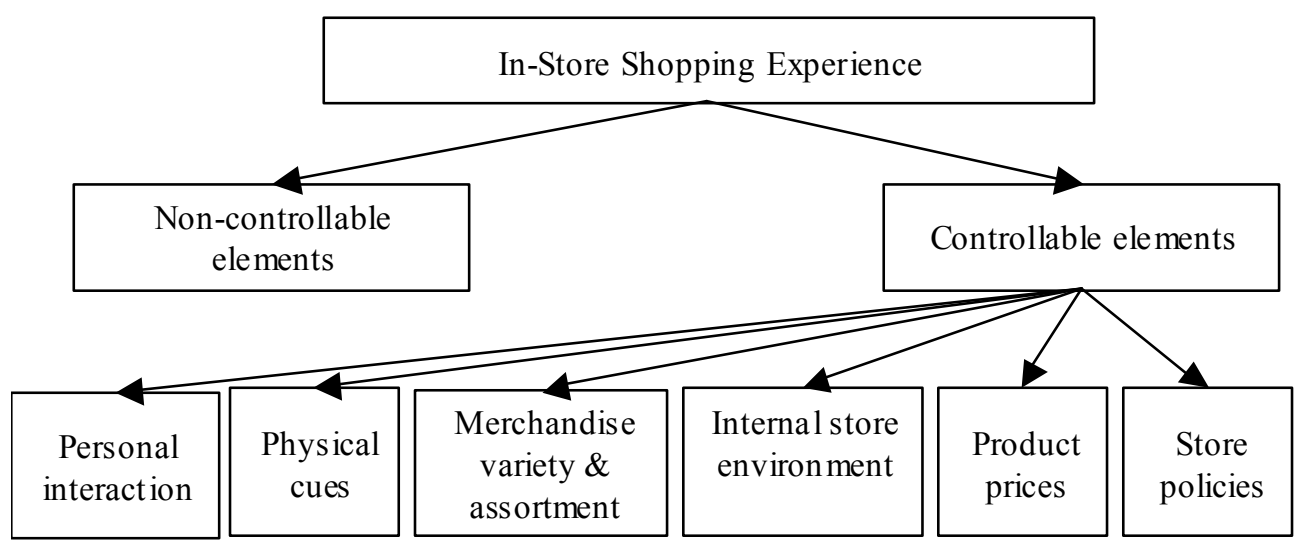

Figure 1: Schematic presentation of the dimensions of ISE tested in the second phase of the study

\section{Sample and data collection: second survey}

The sampling procedure used in this study was a combination of convenience and random sampling. Respondents were visitors to two regional shopping centres. Individual respondents (visitors) to be interviewed were selected on a simple random basis. Personal interviews, using a structured questionnaire, were conducted with visitors to the shopping centre after they exited the building on their way out. The interviews were conducted over a period of two days, a Friday and a Saturday. In previous studies these two days were found to include all the different types of visitors that usually frequent these shopping centers. Respondents were asked to rate the importance of the various components of ISE on a 7-point scale where a 7 meant that the aspect under consideration is 'extremely important' and a 1 meant that it is 'not important'. A total of 2504 questionnaires were completed of which 1197 were supermarkets customers and 1307 clothing stores customers. The questions were in respect of a supermarket and a clothing shore in general and not a specific retailer.

\section{Empirical results: second survey}

The second survey data analyses procedures again closely followed the guidelines for scale development suggested by Churchill (1979). To assess the discriminant validity of the instrument a Maximum Likelihood Exploratory Factor Analysis was again conducted specifying a Direct Quartimin oblique rotation (Jennrich \& Sampson, 1966) of the original factor matrix.

Although it was expected that a six-factor solution would emerge (in line with Figure 1) several different factor solutions were considered. The most interpretable factor structure (factor loading exceeding 0,4 and no crossloadings) to emerge was a 5-factor solution (Table 2). Four of the five factors in Table 2 had Eigen values above 1,00 and a sufficient number of items loading on them to a significant $(0,40)$ extent (Hair, Anderson, Tatham \& Black, 1998). The three factors retained from the first survey (Personal Interaction, Physical Cues and Product Variety and Assortment) remained stable during the second survey. Of the 'new' dimensions added for the second survey Store Policies emerged as a separate factor as expected. Many of the items expected to measure Physical Cues and Product Prices, however, loaded on a common factor that was labeled Merchandise Value (Table 2). As some items expected to measure Physical Cues now loaded on the factor Merchandise Value the remaining items were in fact measurements of Store Environment, and were thus labeled as such. The items that remained measuring the dimension Store Policies after the scale purification process all referred to the narrower concept Complaint Handling rather than the broader Store Policies and it was thus re-named as well. A separate analysis of the supermarket and clothing store results did not reveal significant differences between the responses in respect of the two groups of respondents.

Table 2: Rotated factor loadings

\begin{tabular}{l|c|c|c|c|c}
\hline & Factor1 & Factor2 & Factor3 & Factor4 & Factor5 \\
\hline Items & $\begin{array}{c}\text { Merchandi } \\
\text { se value }\end{array}$ & $\begin{array}{c}\text { Internal } \\
\text { store } \\
\text { environ- } \\
\text { ment }\end{array}$ & $\begin{array}{c}\text { Personal } \\
\text { interaction }\end{array}$ & $\begin{array}{c}\text { Merchandi } \\
\text { se variety }\end{array}$ & $\begin{array}{c}\text { Complaint } \\
\text { handling }\end{array}$ \\
\hline PRICE1 & $\mathbf{0 , 6 2 4}$ & 0,064 & 0,026 & $-0,055$ & $-0,026$ \\
\hline PHYS2 & $\mathbf{0 , 6 2 3}$ & 0,034 & 0,045 & $-0,013$ & 0,025 \\
\hline PRICE2 & $\mathbf{0 , 6 0 5}$ & 0,108 & 0,017 & $-0,056$ & 0,112 \\
\hline PHYS1 & $\mathbf{0 , 6 0 1}$ & $-0,118$ & 0,028 & 0,002 & $-0,004$ \\
\hline PRICE3 & $\mathbf{0 , 5 1 2}$ & 0,080 & 0,064 & 0,061 & 0,108 \\
\hline VAR1 & $\mathbf{0 , 5 0 4}$ & 0,033 & $-0,014$ & 0,140 & $-0,059$ \\
\hline VAR2 & $\mathbf{0 , 4 4 8}$ & 0,033 & 0,050 & 0,167 & $-0,016$ \\
\hline PHYS3 & $\mathbf{0 , 4 4 4}$ & $-0,065$ & 0,021 & 0,018 & 0,178 \\
\hline ENV8 & 0,025 & $\mathbf{0 , 7 3 9}$ & $-0,044$ & 0,035 & 0,035 \\
\hline PHYS6 & 0,106 & $\mathbf{0 , 6 9 5}$ & 0,021 & $-0,082$ & 0,100 \\
\hline ENV5 & 0,008 & $\mathbf{0 , 6 5 5}$ & 0,009 & 0,118 & 0,019 \\
\hline PHYS4 & $-0,056$ & $\mathbf{0 , 6 5 2}$ & 0,100 & 0,071 & $-0,102$ \\
\hline ENV6 & $-0,005$ & $\mathbf{0 , 4 0 2}$ & 0,063 & 0,208 & 0,168 \\
\hline PERS3 & $-0,139$ & 0,126 & $\mathbf{0 , 6 5 4}$ & 0,028 & $-0,029$ \\
\hline PERS2 & 0,171 & $-0,092$ & $\mathbf{0 , 6 5 1}$ & $-0,020$ & 0,001 \\
\hline PERS4 & 0,034 & 0,036 & $\mathbf{0 , 6 2 3}$ & 0,049 & 0,090 \\
\hline PERS5 & 0,058 & 0,059 & $\mathbf{0 , 4 8 9}$ & $-0,017$ & 0,206 \\
\hline PERS6 & $-0,045$ & 0,012 & $\mathbf{0 , 4 8 6}$ & 0,086 & 0,306 \\
\hline PERS1 & 0,095 & $-0,005$ & $\mathbf{0 , 4 5 8}$ & 0,015 & $-0,039$ \\
\hline VAR3 & $-0,051$ & 0,042 & 0,029 & $\mathbf{0 , 7 0 7}$ & $-0,036$ \\
\hline VAR7 & 0,028 & 0,031 & 0,010 & $\mathbf{0 , 6 8 8}$ & 0,035 \\
\hline VAR4 & 0,054 & 0,021 & $-0,001$ & $\mathbf{0 , 6 7 2}$ & 0,042 \\
\hline VAR6 & 0,126 & 0,040 & 0,019 & $\mathbf{0 , 5 1 9}$ & 0,108 \\
\hline POL6 & $-0,018$ & 0,041 & 0,050 & 0,092 & $\mathbf{0 , 7 3 7}$ \\
\hline POL5 & 0,074 & 0,039 & 0,008 & 0,039 & $\mathbf{0 , 6 5 3}$ \\
\hline POL7 & 0,083 & 0,025 & 0,110 & 0,023 & $\mathbf{0 , 6 4 0}$ \\
\hline Eigen values & 8,52 & 2,61 & 1,61 & 1,11 & 0,94 \\
\hline Cronbach & 0,819 & 0,832 & 0,813 & 0,799 & 0,817 \\
Alpha & & & & & \\
\hline & & & & & \\
\hline
\end{tabular}

*PRICE=Product prices; PHYS=Physical cues; ENV=Internal store environment; $\mathrm{VAR}=$ Product variety and assortment; PERS=Personal interaction; $\mathrm{POL}=$ Store policies. 


\section{Reliability assessment}

The assessment of the proposed instrument's discriminant validity by means of an exploratory factor analysis was followed by an assessment of the internal consistency of each dimension as suggested by Churchill (1979). As indicated at the bottom of Table 2, all five factors/dimensions returned Cronbach Alpha values above the customary cut-off of 0,7 (Peterson, 1994). The Cronbach Alpha co-efficient for the whole instrument was 0,916.

\section{Convergent validity}

Any measuring instrument should be both reliable and valid (Churchill, 1979). A variety of different types of validity should be considered before any claims of validity can be made (Tull \& Hawkins, 1993). To test the convergent validity of the ISE instrument the total ISE score (mean 153,52: SD 18,04) was correlated with scores that was expected to measure consumer perceptions of three retail issues that would be positively associated with ISE namely: the adequacy of parking facilities, satisfaction with in-store promotions and the image of the store.

The empirical results reported in Table 3 confirm this contention. The Pearson correlation coefficients shown in Table 3 reveal a consistent pattern of significant positive correlations with the total ISE scores, namely perceptions of adequacy of parking facilities (PARK, mean 6,30, SD 1,22), satisfaction with special in-store promotions (SPEC, mean $5,32, \mathrm{SD} 1,51$ ) and the image of the company (IMAGE, mean 5,75, SD 1,41), confirming the convergent validity of the ISE instrument.

Table 3: Correlation matrix of in-store shopping experience, parking, store promotions and company image

\begin{tabular}{c|c|c|c|c}
\hline & ISE & PARK & SPEC & IMAGE \\
\hline ISE & 1,00000 & & & \\
& 0,0 & & & \\
\hline PARK & 0,41390 & 1,0000 & & \\
& 0,0001 & 0,0 & & \\
\hline SPEC & 0,46629 & 0,18971 & 1,00000 & \\
& 0,0001 & 0,0001 & 0,0 & \\
\hline IMAGE & 0,44806 & 0,21581 & 0,46911 & 1,0000 \\
& 0,0001 & 0,0001 & 0,0001 & 0,0 \\
\hline
\end{tabular}

\section{Construct validity}

To assess the construct validity of the instrument a confirmatory factor analysis was conducted using LISREL 8,30 (Joreskog \& Sörbom, 1999). The results summarised in Table 4 and Figure 2 suggest a good fit of the model to the data $\left(\chi^{2}=2024,5\right.$; df $=289$; RMSEA $=0,0504$; GFI $=$ 0,939; AGFI $=0,925$; an ECVI $=0,900)$. The reasonable fit of the model to the data provides additional evidence of the construct validity of the proposed instrument.

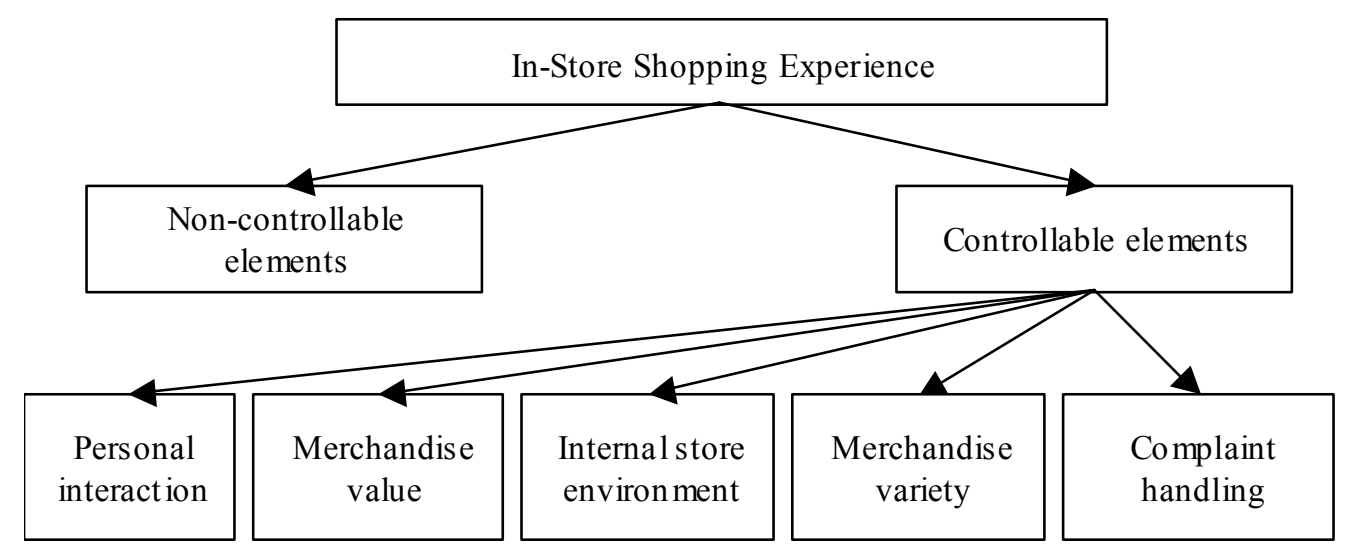

Figure 2: Empirical results of Survey 2 
Table 4: Model fit indices

\begin{tabular}{l|c}
\hline Chi-square & 2024,5 \\
\hline df & 289 \\
\hline RMSEA & 0,0504 \\
\hline ECVI & 0,900 \\
\hline Normed fit index (NFI) & 0,921 \\
\hline Comparative fit index (CFI) & 0,931 \\
\hline Standardised RMR & 0,047 \\
\hline GFI & 0,939 \\
\hline AGFI & 0,925 \\
\hline PGFI & 0,773 \\
\hline
\end{tabular}

\section{Conclusion}

This study reports on two phases of a long-term study on the controllable elements of the in-store shopping experience. The eventual outcome of this stream of research is to develop a reliable and valid instrument to measure customer satisfaction with the controllable components of the in-store shopping experience at store level. Closely following the guidelines for multi-item scale development suggested by Churchill (1979) and based on the results of two empirical surveys we conclude that there are five dimensions of importance to consumers when assessing their satisfaction with an in-store shopping experience. These dimensions are merchandise value, personal interaction, merchandise variety, internal store environment and complaint handling. These five dimensions and thus the in-store shopping experience, are measured by means of 26 items (see Appendix A). The proposed instrument in its current form demonstrates high levels of reliability, discriminant validity, convergent validity and construct validity. Consistent with the guidelines suggested by Churchill (1979) the instrument in its current form needs to be subjected to a third empirical assessment to provide conclusive evidence of the its psychometric properties.

\section{References}

Anderson, E.W., Fornell, C. \& Lehmann, D.R. 1994. 'Customer satisfaction, market share, and profitability: Findings from Sweden', Journal of Marketing, 58:53-66.

Anthanassopoulos, A.D. 2000. 'Customer satisfaction cues to support market segmentation and explain switching behaviour', Journal of Business Research, 47(3):191-207.

Bateson, J.G. \& Hoffmann, K.D. 1999. Managing services marketing. $4^{\text {th }}$ Edition. Fort Worth: Dryden.

Beatty, S.E., Mayer, M.L., Coleman, J.E., Reynolds, K.E. \& Lee, J. 1996. 'Customer-sales associate retail relationships', Journal of Retailing, 72:223-247.

Berman, B. \& Evans, J. R. 1998. Retail management. $7^{\text {th }}$ Edition. Upper Saddle River: Prentice Hall.

Berry, L.L. \& Gresham, L.G. 1986. 'Relationship retailing: Transforming customers into clients', Business Horizons, 29(6):43-47.
Berry, L.L. \& Parasuraman, A. 1991. Marketing services. New York: Free Press.

Bingham, F.G. \& Raffield, B.T. 1990. Business-to-business marketing management. Homewood, Illinois: Irwin.

Bitner, M.J. 1990. 'Evaluating service encounters: The effects of physical surroundings and employee responses', Journal of Marketing, 54:69-82.

Bitner, M.J. 1992. 'Servicescapes: The impact of physical surroundings on customers and employees', Journal of Marketing, 56:57-71.

Bloemer, J. \& de Ruyter, K. 1998. 'On the relationship between store image, store satisfaction and store loyalty', European Journal of Marketing, 32(5/6):499-513.

Bloom, P.H. \& Reve, T. 1990. 'Transmitting signals to consumers for competitive advantage', Business Horizons, 33(4):58-66.

Churchill, G.A. (Jr). 1979. 'A paradigm for developing better measures of marketing constructs', Journal of Marketing Research, XVI:64-73.

Cronin, J.J. (Jr), Brady, M.K. \& Hult, G.T. 2000. 'Assessing the effects of quality, value, and customer satisfaction on consumer behavioural intentions in service environments', Journal of Retailing, 76(2):193-218.

Dabholkar, P. A., Thorpe, D. I. \& Rentz, J. O. 1996. 'A measure of service quality for retail stores: Scale development and validation', Journal of the Academy of Marketing Science, 24(1):3-16.

Darden, W.R., Erdem, O. \& Darden, D.K. 1983. 'A comparison and test of three causal models of patronage intentions'. In Darden, W.R. \& Lusch R.F. (Eds.). Patronage behavior and retail management. New York: North-Holland.

Davidson, W.R., Sweeney, D.J. \& Stampfl, R.W. 1988. Retail management. $6^{\text {th }}$ Edition. New York: John Wiley \& Sons.

Dickson, J. \& Albaum, G. 1977. 'A method for developing tailormade semantic differentials for specific marketing content areas', Journal of Marketing Research, 14:87-91.

Dickson, J.P. \& MacLachlin, D.L. 1990. 'Social distance and shopping behaviour', Journal of the Academy of Marketing Science, 18(2):153-161.

Dodds, W.B., Monroe, K.B. \& Grewal, D. 1991. 'Effects of price, brand, and store information on buyers' product evaluations', Journal of Marketing Research, XXVII:307319.

Donavon, R.J. \& Rossiter, J.R. 1982. 'Store atmosphere: An environmental psychology approach', Journal of Retailing, 58:39-52. 
Gaski, J.F. \& Etzel, M.J. 1986. 'The index of consumer sentiment toward marketing', Journal of Marketing, 50:7181.

Grönroos, C. 1990. 'Relationship approach to marketing in service contexts: The marketing and organizational behavior interface', Journal of Business Research, 20:3-11.

Gutman, J. \& Alden, S.D. 1985. 'Adolescents' cognitive structures of retail stores and fashion consumption: A means-end chain analysis of quality'. In Jacoby J. \& Olsen J. (Eds.). Perceived quality: How consumers view stores and merchandise. Lexington, M.A.: Lexington Books.

Hair, J. F. (Jr), Anderson, R.E., Tatham, R. L. \& Black, W. C. 1998. Multivariate data analysis. $5^{\text {th }}$ Edition. Upper Saddle River: Prentice Hall.

Hallowell, R. 1996. 'The relationship of customer satisfaction, customer loyalty and profitability: An empirical study', The International Journal of Service Industry Management, 7(4):27-42.

Hasty, R. \& Reardon, J. 1997. Retail management. New York: McGraw-Hill.

Heskett, J.L., Jones, T.O., Loveman, G.W., Sasser, W.E. (Jr) \& Schlesinger, L.A. 1994. 'Putting the service-profit chain to work', Harvard Business Review, 72(2):164-174.

Hummel, J.W. \& Savitt, R. 1988. 'Integrated customer service and retail strategy', International Journal of Retailing, 3(2):5-21.

Jennrich, R.I. \& Sampson, P.F. 1966. 'Rotation for simple loadings', Psychometrika, 31:313-323.

Jöreskog, K. \& Sörbom, D. 1999. 'LISREL 8.30 Manual for Windows' (Computer software). Lincolnwood, IL: Scientific Software International, Inc.

Kerin, R.A., Jain, A. \& Howard, D.J. 1992. 'Store shopping experience and consumer price-quality-value perceptions', Journal of Retailing, 68(4):376-397.

Macintosh, G. \& Lockshin, L.S. 1997. 'Retail relationships and store loyalty: A multi-level perspective', International Journal of Research in Marketing, 14(5):487-497.

Mazursky, D., \& Jacoby, J. 1985. 'Forming impressions of merchandise and service quality'. In Jacoby, J. \& Olsen, J. (Eds.). Perceived quality: How consumers view stores and merchandise. Lexington, M.A.: Lexington Books.

Oliver, R. 1981. 'Measurement and evaluation of satisfaction processes in retail settings', Journal of Retailing, 57:25-48.

Oliver, R.L. 1997. Satisfaction: A behavioral perspective on the consumer. Boston: Irwin McGraw-Hill.
Peterson, R.A. 1994. 'A meta-analysis of Cronbach's coefficient alpha', Journal of Consumer Research, 27:381391.

Rao, A.R. \& Monroe, K.B. 1989. 'The effect of price, brand name and store name on buyers' perceptions of product quality: An integrative review', Journal of Marketing Research, 26:351-357.

Reichheld, F. \& Sasser, W.E. (Jr). 1990. 'Zero defections: Quality comes to services', Harvard Business Review, 68:105-111.

Ridgeway, N.M., Dawson, S.A. \& Bloch, P.H. 1990. 'Pleasure and arousal in the marketplace: Interpersonal differences in approach-avoidance responses', Marketing Letters, 7:139-147.

Rosenberg, L.J. \& Czepiel, J.A. 1984. 'A marketing approach to customer retention', Journal of Consumer Marketing, 1:45-51.

Rust, R.T. \& Zahorik, A.J. 1993. 'Customer satisfaction, customer retention, and market share', Journal of Retailing, 69:193-215.

Samli, A.C., Kelley, J.P. \& Hunt, H.K. 1998. 'Improving the retail performance by contrasting management- and customer-perceived store images: A diagnostic tool for corrective action', Journal of Business Research, 43(1):2738 .

Singh, J. \& Sirdeshmukh, D. 2000. 'Agency and trust mechanisms in consumer satisfaction and loyalty judgments', Journal of the Academy of Marketing Science, 28(1):150-167.

Sirgy, M.J., Grewal, D. \& Mangleburg, T. 2000. 'Retail environment, self-congruity and retail patronage: An integrative model and a research agenda', Journal of Business Research, 49(2):127-138.

Sirohi, N., McLaughlin, E.W. \& Wittink, D.R. 1998. 'A model of consumer perceptions and store loyalty intentions for a supermarket retailer', Journal of Retailing, 74(2):223245.

Terblanche, N.S. \& Boshoff, C. 2001. 'Measuring customer satisfaction with some of the controllable elements of the total retail experience: An exploratory study', South African Journal of Business Management, 32(2):35-41.

Tull, D.S. \& Hawkins, D.I. 1993. Marketing research: Measurement and method. $6^{\text {th }}$ Edition. New York: Macmillan.

Ward, J.C., Barnes, J. \& Bitner, J. 1992. 'Measuring the prototypicality and meaning of retail environments', Journal of Retailing, 68:194-220.

Westbrook, R.A. 1981. 'Sources of consumer satisfaction with retail outlets', Journal of Retailing, 57:68-85. 
Zeithaml, V.1988. 'Consumer perceptions of price, quality, and value: A means-end model and synthesis of evidence', Journal of Marketing, 52:2-22.

Zeithaml, V.A. \& Bitner, M.J. 1996. Services marketing. New York: McGraw-Hill.

Zeithaml, V.A., Parasuraman, A. \& Berry, L.L. 1990. Delivering quality service: Balancing customer perceptions and expectations. New York: The Free Press. 
APPENDIX A

ITEMS TO MEASURE THE IN-STORE SHOPPING EXPERIENCE OF CUSTOMERS

\begin{tabular}{|l|l|}
\hline $\begin{array}{l}\text { Merchandise } \\
\text { value }\end{array}$ & \\
\hline MEVAL1 & Reasonable prices \\
\hline MEVAL2 & Products of good quality \\
\hline MEVAL3 & Prices that offer value for money \\
\hline MEVAL4 & Products that function the way they are supposed to \\
\hline MEVAL5 & Products at prices that represent good value \\
\hline MEVAL6 & A satisfactory choice of products \\
\hline MEVAL7 & A shop that has all the products that ought to be there \\
\hline MEVAL8 & Products that are free from defects and flaws \\
\hline $\begin{array}{l}\text { Internal store } \\
\text { environment }\end{array}$ & \\
\hline STENV1 & Attractive décor \\
\hline STENV2 & Attractive physical facilities (check-out counters, shelves, etc) \\
\hline STENV3 & Attractive product and promotional displays \\
\hline STENV4 & Attractive materials associated with the service (shopping bags, catalogues, etc) \\
\hline STENV5 & Well-spaced product displays \\
\hline $\begin{array}{l}\text { Personal } \\
\text { interaction }\end{array}$ & \\
\hline PERSIN1 & Staff that give me personal attention \\
\hline PERSIN2 & Staff are always willing to help me \\
\hline PERSIN3 & Staff that provide me with prompt service \\
\hline PERSIN4 & Staff that are courteous \\
\hline PERSIN5 & Staff that are never too busy to assist me \\
\hline PERSIN6 & Staff that understand my specific needs \\
\hline $\begin{array}{l}\text { Merchandise } \\
\text { variety }\end{array}$ & \\
\hline VAROS1 & A choice of different brand names \\
\hline VAROS2 & A good selection of well-known brands \\
\hline VAROS 3 & A variety of brand names that are available in many different sizes \\
\hline VAROS 4 & A wide variety of products \\
\hline $\begin{array}{l}\text { Complaint } \\
\text { handling }\end{array}$ & \\
\hline COHAN1 & An effective means of dealing with customer enquiries \\
\hline COHAN2 & A fair system for the handling of complaints \\
\hline COHAN3 & Staff that efficiently deal with customer complaints \\
\hline
\end{tabular}


